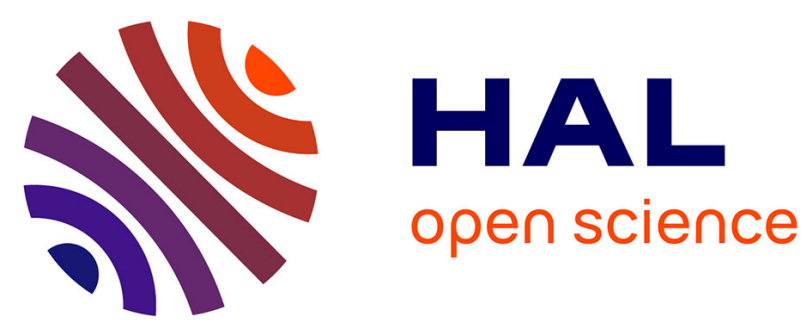

\title{
Distribution of genovars and the new variant of in the Göteborg area, Sweden
}

\author{
T. Lagergård, R. Hadad, P. Tunbäck, L. Lindholm, G.-B. Löwhagen, M. \\ Unemo
}

\section{- To cite this version:}

T. Lagergård, R. Hadad, P. Tunbäck, L. Lindholm, G.-B. Löwhagen, et al.. Distribution of genovars and the new variant of in the Göteborg area, Sweden. European Journal of Clinical Microbiology and Infectious Diseases, 2010, 29 (5), pp.609-611. 10.1007/s10096-010-0887-1 . hal-00570704

\section{HAL Id: hal-00570704 https://hal.science/hal-00570704}

Submitted on 1 Mar 2011

HAL is a multi-disciplinary open access archive for the deposit and dissemination of scientific research documents, whether they are published or not. The documents may come from teaching and research institutions in France or abroad, or from public or private research centers.
L'archive ouverte pluridisciplinaire HAL, est destinée au dépôt et à la diffusion de documents scientifiques de niveau recherche, publiés ou non, émanant des établissements d'enseignement et de recherche français ou étrangers, des laboratoires publics ou privés. 


\title{
Distribution of Chlamydia trachomatis omp $A$ genovars and the new variant of $C$. trachomatis in the Göteborg area, Sweden
}

\author{
T. Lagergård • R. Hadad $\cdot$ P. Tunbäck $\cdot$ L. Lindholm • \\ G.-B. Löwhagen • M. Unemo
}

Received: 30 September 2009 / Accepted: 30 January 2010/Published online: 1 March 2010

(C) Springer-Verlag 2010

\begin{abstract}
The aims of this study were to assess the proportion of the new variant of Chlamydia trachomatis (nvCT) and the distribution of ompA genovars among $C$. trachomatis-positive patients in the Göteborg area, Sweden. Consecutive urine samples positive for $C$. trachomatis using BD ProbeTec ET (177 patients, 88 men and 89 women) were collected. An nvCT-specific real-time polymerase chain reaction (PCR) assay was used to investigate the nvCT prevalence. To identify the genovars, a 990-bp отрA DNA segment from 105 specimens was sequenced. Seventeen percent $(30 / 177)$ of all specimens contained nvCT. Nine different genovars were identified. About 50\% were of genovar $\mathrm{E}$, followed by $\mathrm{F} 16 \%$, G $11 \%$, K $8 \%$, and D $5 \%$, representing about $90 \%$ of the specimens in Göteborg. The occurrence of nvCT and the dominance of genovar E in Göteborg is similar to those in other areas of Sweden. To cover about $90 \%$ of the C. trachomatis
\end{abstract}

\section{T. Lagergård $(\bowtie)$}

Department of Biomedicine, Microbiology and Immunology,

Göteborg University, The Sahlgrenska Academy,

Box 435, 40530 Göteborg, Sweden

e-mail: teresa.lagergard@microbio.gu.se

R. Hadad • M. Unemo

Department of Laboratory Medicine, Clinical Microbiology,

Örebro University Hospital,

Örebro, Sweden

P. Tunbäck · G.-B. Löwhagen

Department of Dermatology, The Sahlgrenska Academy,

Göteborg, Sweden

L. Lindholm

Gotagene AB,

Göteborg, Sweden infections in Sweden, the serovars D, E, F, G, and $\mathrm{K}$ should be included in future vaccines based on the major outer membrane protein.

\section{Introduction}

Chlamydia trachomatis genital infections, commonly asymptomatic, are the most prevalent worldwide bacterial sexually transmitted infection (STI), with considerable morbidity and sequelae, leading to socioeconomic consequences $[1,2]$.

Laboratory diagnosis based on nucleic acid amplification tests (NAATs) provide high sensitivity, high specificity, and are routinely used for the diagnosis of $C$. trachomatis infections $[1,3]$.

C. trachomatis strains are, nowadays, classified into genovars using polymerase chain reaction-restriction fragment length polymorphism (PCR-RFLP) or sequencing of the ompA gene, which encodes the major outer membrane protein (MOMP). Serotypes A-C cause primarily trachoma/ blindness, D-K cause urogenital infections, and L1 -3 the invasive lymphogranuloma venereum (LGV) $[1,2]$. In most countries worldwide, the most common genovars among patients with urogenital infections are E, F, D, G (D and G are particularly prevalent in men who have sex with men [MSM)], and K, accounting for 60 to $80 \%$ of positive patients. The remaining genovars are less frequent, and $\mathrm{Ba}$ and Ia are rare. The urogenital genovars distribution shows some variations, especially among countries on different continents [1, 3-6]. In Sweden, the most prevalent genovars found have been $\mathrm{E}(47-60 \%)$ and $\mathrm{F}$, followed by $\mathrm{D}, \mathrm{K} / \mathrm{G}$ [1]. Genovar determination of $C$. trachomatis can be important in descriptive epidemiology and in basic research aiming to develop future vaccines. No effective vaccine 
Table 1 Chlamydia trachomatis ompA genovar distribution by gender of 105 urogenital isolates in the Göteborg area, Sweden

\begin{tabular}{llll}
\hline Genovar & $\begin{array}{l}\text { Women }(n=44) \\
\text { No. }(\%)\end{array}$ & $\begin{array}{l}\text { Men }(n=61) \\
\text { No. }(\%)\end{array}$ & $\begin{array}{l}\text { Total }(n=105) \\
\text { No. }(\%)\end{array}$ \\
\hline Ba & $1(2.3)$ & 0 & $1(1.0)$ \\
D & $2(4.55)$ & $3(4.9)$ & $5(4.8)$ \\
E & $23(52.3)$ & $29(47.6)$ & $52(49.5)$ \\
F & $6(13.6)$ & $11(18.0)$ & $17(16.2)$ \\
G & $4(9.05)$ & $8(13.1)$ & $12(11.4)$ \\
H & $2(4.55)$ & $2(3.3)$ & $4(3.8)$ \\
Ia & $2(4.55)$ & 0 & $2(1.9)$ \\
J & $2(4.55)$ & $2(3.3)$ & $4(3.8)$ \\
K & $2(4.55)$ & $6(9.8)$ & $8(7.6)$ \\
\hline
\end{tabular}

There was no significant difference in the type distribution between sexes $\left(\chi^{2}\right.$ test $)$

has, so far, been developed, but some MOMP-based vaccines may be promising [2].

In 2006, a new variant of $C$. trachomatis (nvCT) was discovered in Sweden, with a 377-bp deletion in the cryptic plasmid that included the genetic targets for the diagnostic systems from Roche and Abbott [7,8]. The nvCT strain, thus, escaped the detection and spread significantly (proportions of 7 to 64\%) in many Swedish counties [7-9]. In Göteborg, the BD ProbeTec ET (Becton Dickinson) NAAT, which detects the nvCT, has been used since 2001. The nvCT has not been frequently found in other European countries [7, 9]; however, few recent studies have been performed and many laboratories in several countries still cannot detect the nvCT.

The aims of this study were to investigate, for the first time, the proportion of the $\mathrm{nvCT}$ and the distribution of different genovars among patients with $C$. trachomatis infections in the Göteborg area, Sweden.

\section{Materials and methods}

Consecutive urine samples from 89 women (age: 16-49 years) and 88 men (age: 17-44 years) positive for $C$. trachomatis in routine testing using the BD ProbeTec ET test (Becton Dickinson, Franklin Lakes, NJ, USA) were collected from October 2008 to January 2009. For nvCT detection, an nvCT-specific real-time PCR was used on all primary samples $(n=177)$ as previously described [10]. To assess the genovar distribution, a 990-bp отрA segment of the first 112 selected primary specimens (from 44 women and 61 men) were sequenced as previously described [11]. However, seven of these failed to amplify, probably due to the low initial positivity in BD ProbeTec ET, and were excluded. For the identification of genovars, phylogenetic analysis, as well as GenBank blasting, were performed as previously described [11].

\section{Results and discussion}

The nvCT proportion in the Göteborg area, Sweden, has not been previously studied. The nvCT was detected in $17 \%$ of all the specimens $(n=177)$, showing that the nvCT proportion is relatively similar to those in other Swedish counties that used BD ProbeTec (7-19\%) for the diagnosis of $C$. trachomatis, which, in general, is lower than the proportions in the Swedish counties using Roche and Abbott systems for diagnostics [7].

The frequencies for the predominant ompA genovars identified in the Göteborg area were approximately E 50\%, followed by F 16\%, G 10\%, K 8\%, and D 5\% (Table 1). These genovars represented approximately $90 \%$ of all the $C$. trachomatis-positive specimens. We did not find any unpreviously reported single nucleotide polymorphisms (SNPs) or other polymorphisms in the ompA gene within the genovars, or any significant differences in genovar distribution related to the gender or age of the patients. Inclusion of only the three most common serotypes in a vaccine based on the MOMP will cover about $76 \%$, and inclusion of the five serotypes $\mathrm{D}$, E, F, G, and K will account for almost $90 \%$ of all urogenital strains in this geographic area. The proportions of different genovars/serovars, especially concerning the dominance of genovar E, are similar to those found in other studies performed in Sweden, especially in the Örebro area, where the same 990-bp ompA segment was used for the study [11]. Genovar E represents from 39 to $60 \%$ of isolates $[1,3,11]$. Similar dominance of genovars, and especially E, has also been reported from many other European countries [3]. However, in different populations, such as, e.g., in MSM from Sweden, the occurrence of other genovars such as D/Da (25-54\%) and $G(25-45 \%)$ was higher compared with a heterosexual population, which is also in concordance with previous studies from other countries $[3,4]$.

MOMP is perhaps the most promising antigen candidate for a vaccine [2], and the D, E, F, G, and K strains account for approximately $90 \%$ of the C. trachomatis infections in Sweden and Denmark. It is notable that, in one study from Cameroon, a similar prevalence as in European countries was noted and strains D, E, F, and G accounted for $94 \%$ of isolates [6]. Among patients with an STI in Asia, e.g., China, genotype $\mathrm{E}$ is not dominating, but the most common serovars D, E, F, and G are more equally distributed and together account for about $75 \%$ of all serotypes [5]. The results indicated that the most common worldwide serovars $\mathrm{D}, \mathrm{E}, \mathrm{F}$, and $\mathrm{G}$ should be considered in the development of an effective MOMP-based vaccine. 
Acknowledgments This study was supported by the Swedish Research Council (K2007-58X-20365-01-3), ALF/LUA, Göteborg, and The Royal Society of Arts and Sciences in Göteborg (KVVS).

\section{References}

1. Persson K (2002) The role of serology, antibiotic susceptibility testing and serovar determination in genital chlamydial infections. Best Pract Res Clin Obstet Gynaecol 16(6):801-814

2. Hafner L, Beagley K, Timms P (2008) Chlamydia trachomatis infection: host immune responses and potential vaccines. Mucosal Immunol 1(2):116-130

3. Pedersen LN, Herrmann B, Møller JK (2009) Typing Chlamydia trachomatis: from egg yolk to nanotechnology. FEMS Immunol Med Microbiol 55(2):120-130

4. Millman K, Black CM, Stamm WE et al (2006) Population-based genetic epidemiologic analysis of Chlamydia trachomatis serotypes and lack of association between ompA polymorphisms and clinical phenotypes. Microbes Infect 8(3):604-611

5. Gao X, Chen XS, Yin YP et al (2007) Distribution study of Chlamydia trachomatis serovars among high-risk women in
China performed using PCR-restriction fragment length polymorphism genotyping. J Clin Microbiol 45(4):1185-1189

6. Ngandjio A, Clerc M, Fonkoua MC et al (2004) Restriction endonuclease patterns of the ompl gene of reference Chlamydia trachomatis strains and characterization of isolates from Cameroonian students. J Med Microbiol 53(Pt 1):47-50

7. Herrmann B, Törner A, Low N et al (2008) Emergence and spread of Chlamydia trachomatis variant, Sweden. Emerg Infect Dis 14 (9):1462-1465

8. Ripa T, Nilsson P (2006) A variant of Chlamydia trachomatis with deletion in cryptic plasmid: implications for use of PCR diagnostic tests. Euro Surveill 11(11):E061109.2

9. Unemo M, Rossouw A, James V et al (2009) Can the Swedish new variant of Chlamydia trachomatis (nvCT) be detected by UK NEQAS participants from seventeen European countries and five additional countries/regions in 2009? Euro Surveill 14(19), art 19206

10. Ripa T, Nilsson PA (2007) A Chlamydia trachomatis strain with a 377-bp deletion in the cryptic plasmid causing false-negative nucleic acid amplification tests. Sex Transm Dis 34(5):255-256

11. Jurstrand M, Falk L, Fredlund H et al (2001) Characterization of Chlamydia trachomatis ompl genotypes among sexually transmitted disease patients in Sweden. J Clin Microbiol 39(11):39153919 